\title{
Responding to the COVID-19 Pandemic in Developing Countries: Lessons from Selected Countries of the Global South
}

\author{
Anis Z. Chowdhury ${ }^{1} \cdot$ K. S. Jomo ${ }^{2}$ \\ Published online: 10 November 2020 \\ (c) Society for International Development 2020
}

\begin{abstract}
Reviewing selected policy responses in Asia and South America, this paper draws pragmatic lessons for developing countries to better address the COVID-19 pandemic. It argues that not acting quickly and adequately incurs much higher costs. So-called 'best practices', while useful, may be inappropriate, especially if not complemented by effective and suitable socio-economic measures. Public understanding, support and cooperation, not harsh and selective enforcement of draconian measures, are critical for successful implementation of containment strategies. This requires inclusive and transparent policy-making, and well-coordinated and accountable government actions that build and maintain trust between citizens and government. In short, addressing the pandemic crisis needs 'all of government' and 'whole of society' approaches under credible leadership.
\end{abstract}

Keywords COVID-19 pandemic · Contagion · Precautionary measures · Herd immunity · Containment measures · Lockdown $\cdot$ Physical distancing $\cdot$ Contact tracing $\cdot$ Health systems

After the first outbreak in China in late 2019, COVID-19 initially seemed to bypass much of the Global South, especially sub-Saharan Africa, perhaps reflecting the contribution of passenger air travel to its uneven global spread. Nevertheless, the fear of the contagion's devastating impacts in developing countries continues to grow (Malley and Malley 2020; Faiola et al. 2020; Muggah and Florida 2020; Porras 2020; Wolf 2020).

On 30 January, when there were 7818 confirmed cases of human-to-human transmission, with the vast majority in

Anis Z. Chowdhury

anis.z.chowdhury@gmail.com

K. S. Jomo

jomoks@yahoo.com

1 School of Social Sciences and Psychology, Western Sydney University, Sydney, Australia

2 Khazanah Research Institute, Kuala Lumpur, Malaysia
China, and 82 cases in 18 countries outside China, the World Health Organization (WHO) designated the COVID-19 outbreak a 'public health emergency of international concern' (PHEIC), raising the global risk of the outbreak to 'high' and for China 'very high', its highest alert level. ${ }^{1}$ The WHO declared COVID-19 a 'pandemic' on 11 March when there were more than 118,000 confirmed cases and 4,291 deaths in 114 countries. $^{2}$

On 31 March, the United Nations (UN) Secretary-General described the COVID-19 crisis as the greatest collective

\footnotetext{
1 When a PHEIC is declared, the WHO Director-General issues temporary recommendations under the 2005 International Health Regulations (IHR), including obligations for countries to provide sufficient public health rationale and justification to WHO about any additional measures beyond what the WHO recommends. This is critical to ensure the international response is evidence-based, measured and balanced, so that unnecessary interference with travel and trade is avoided. The WHO also recommended that the global community should provide support to low- and middle-income countries to respond to the threat, and to facilitate their access to diagnostics, potential vaccines and therapeutics. https://www.euro.who.int/en/ health-topics/health-emergencies/international-health-regulations/ news/news/2020/2/2019-ncov-outbreak-is-an-emergency-of-internatio nal-concern. Accessed 6 May 2020.

2 https://www.who.int/dg/speeches/detail/who-director-general-sopening-remarks-at-the-media-briefing-on-covid-19---11-march -2020. Accessed 3 May 2020.
} 
test for the 'international community' since the UN's formation. ${ }^{3} \mathrm{He}$ urged developed countries to immediately help less developed countries to bolster their health systems and capacity to check disease, especially COVID-19 transmission. Failure to do so, he warned, would contribute to 'the nightmare of the disease spreading like wildfire in the Global South with millions of deaths and the prospect of the disease re-emerging where it was previously suppressed'.

Early precautionary measures in much of the rest of China and East Asia, and in places such as Kerala state in southwest India, were largely successful in containing the spread of the epidemic, at least thus far. But most national authorities outside of East Asia did not take adequate early precautionary measures speedily enough to contain the spread of the outbreak, typically by promoting safe 'physical distancing', obligatory use of masks in public areas, and other measures to reduce the spread and likelihood of infection.

Societal vulnerability to infection and capacity to respond depend on many factors, including health care system preparedness, leadership experience and ability to manage specific challenges posed. Government capacity to respond depends crucially on system capacity and capabilities-e.g., authorities' ability to speedily trace, isolate and treat the infected—and available fiscal resources-e.g., to quickly enhance testing capacity and secure personal protective equipment (PPE). Funding cuts, privatization and other abuses of recent decades - in the face of rising costs, not least for medicines-have further constrained and undermined most public health systems, albeit on various different pretexts. Of course, socio-cultural factors, such as more cooperation due to greater 'trust' in the authority, less individualistic and narcissistic cultures, and even the shared memory and experience of past outbreaks such as SARS and Nipah, have also been important.

This review seeks to draw pragmatic lessons for developing countries to better address the COVID-19 pandemic. It begins with a brief discussion seeking to understand distinctive characteristics of the pandemic infecting a large share of the world's population. It then evaluates the principal strategies adopted to address the health crisis, especially to enable national health systems to cope with the emergency. It is followed by reflections on the causes and implications of public health capacity vulnerabilities in developing countries. Finally, it draws some implications of different policy responses in East Asia, Southeast Asia-especially Vietnam, and India's Kerala state-Argentina, Brazil and Peru, that are relevant for other countries. It argues that the costs

\footnotetext{
3 'Transcript of the UN Secretary-General's virtual press encounter to launch the Report on the Socio-Economic Impacts of Covid-19'. United Nations https://www.un.org/sg/en/content/sg/press-encou nter/2020-03-31/transcript-of-un-secretary-general\%E2\%80\%99svirtual-press-encounter-launch-the-report-the-socio-economic-impac ts-of-covid-19. Accessed 3 August 2020.
}

of not acting quickly and adequately are higher. It further argues that so-called 'best practices', while useful, may be inappropriate, especially if not complemented by effective and suitable socio-economic measures. High degrees of public support and cooperation are critical for successful implementation of containment strategies without having to resort to wasteful and self-defeating draconian measures. This requires inclusive and transparent policy-making, and well-coordinated and accountable government actions that build and maintain trust between citizens and government. In short, addressing a pandemic crisis of this scale needs 'all of government' and 'whole of society' approaches under credible leadership.

\section{The COVID-19 Pandemic: Salient Features}

The COVID-19 pandemic, caused by the SARS-CoV-2 virus, is now widely considered more infectious than other viral epidemics in last century following the 1918 Spanish flu pandemic, especially since the deadly Asian flu of the late 1950s and Hong Kong flu of 1968. ${ }^{4}$ The COVID-19 fatality rate is lower than for the first severe acute respiratory syndrome (caused by SARS-CoV-1) in 2002-2003, ${ }^{5}$ and is not more infectious than the $\mathrm{H} 1 \mathrm{~N} 1$ virus, but has infected many more people nonetheless. ${ }^{6}$

Several factors have made COVID-19 more dangerous than other recent viral epidemics. First, its symptoms and consequences are rather diverse and can be quite severe, varying with age. For example, while COVID-19 primarily affects the respiratory system, causing pneumonia, it has also been associated with gastrointestinal and neurological manifestations (Christakis 2020). Those infected may also mistakenly attribute their symptoms to influenza or other health conditions. Importantly, those infected with the SARS-CoV2 virus may be infectious well before showing any symptoms,

\footnotetext{
${ }^{4}$ Seven coronavirus varieties have infected humans thus far: four caused sniffles, one caused the deadly MERS outbreak in the Middle East, first reported in Saudi Arabia in 2012, with two others causing major international epidemics. The first caused SARS, which petered out quickly, despite its high fatality rate, while the other causes COVID-19.

5 According to the WHO, a total of 8,098 people in 26 countries had SARS; 774 died between November 2002 and July 2003, i.e., a death rate of $9.6 \%$, whereas the COVID-19 death rate was $3.6 \%$, when it was declared a pandemic (Woodley 2020).

${ }^{6}$ Consider two pathogens, $\mathrm{X}$ and Y. For every thousand people, both cause 20 people to become seriously ill, killing two each. But the second pathogen $\mathrm{Y}$ also infects 180 more people, only making them mildly or moderately ill, i.e., not killing them. So, the "case fatality' rate (number of deaths per infected person) for $\mathrm{X}$ is $10 \%$ (2 out of 20), whereas for $\mathrm{Y}$, it is $1 \%$ (2 out of 200). But although this rate is lower for the second pathogen, Y, it is no less lethal (Christakis 2020).
} 
while as many as half of those infected, and hence infectious, may be asymptomatic, i.e., not show any symptoms of illness. Hence, reliable new cheap and rapid tests for COVID19 infection promise to be a major 'game-changer'.

$\mathrm{R}_{0}$ is the average number of individuals that an infected person infects when no interventions have been implemented; this number does not change. The 'reproduction rate' - referred to as $\mathrm{R}_{\mathrm{t}}$ or $\mathrm{R}_{\mathrm{e}}$ depending on preference or convention-will likely change as interventions are put in place, while the number of those susceptible changes due to infection and possible immunity.

Major variations due to 'super spreader' episodes further complicate understanding of the significance of average rates and of variations. While 'super-spreader' episodes have received much publicity, they have been exceptional with a lower variation in $\mathrm{R}_{\mathrm{t}}$ and hence less important for explaining contagion than 'normal' networks of viral transmission of COVID-19. ${ }^{7}$ Again, with a lower fatality rate-the probability of a person dying-COVID-19 has been particularly hard to contain as there are more infectious people around than if it were more deadly. ${ }^{8}$ Hence, movement restrictions, physical distancing, self-isolation and other precautionary and preventive measures are important.

The virus can spread from person to person during close direct or indirect contact with an infectious person (even before they have symptoms), contact with aerosol- or droplet-borne virus from an infected person, either directly or indirectly. Infection, via mucous membranes in the mouth, nose or eyes, starts in the upper respiratory tract, typically in the throat or upper airways. Elderly persons and people with other health issues, such as asthma, diabetes, obesity, hypertension, etc. are more vulnerable, and likely to face complications and death.

Improved understanding of COVID-19 has been critical for designing and improving policy responses. The SARSCoV2 virus was considered novel as it had never been seen in humans before. Thus, initial responses in East, including Southeast Asia were drawn from known 'best practices' for testing, contact tracing, isolation and treatment. But, for various reasons, even these were not done in most countries outside Asia. Once the virus had spread widely, it was no longer practical or even possible to belatedly implement best practices effectively as case-loads not only overwhelmed hospitals, but also public health systems.

Differences with earlier viruses and epidemics meant that simple emulation of past containment measures have not always been appropriate, let alone optimally effective for

\footnotetext{
${ }^{7}$ COVID-19 appears to have lower $\mathrm{R}_{0}$ variation than SARS, for example.

8 This explains why the Ebola epidemics with a terrifying fatality rate $80-90 \%$ waned reasonably quickly.
}

containing COVID-19. Government policymakers need to consider the general nature and specific variations of the COVID-19 pandemic and its uniquely changing and varied implications in particular contexts. A standardized set of interventions, even ostensible best practices, is unlikely to be universally applicable, as the COVID-19 pandemic has different ramifications in varied circumstances over time.

The incubation period ${ }^{9}$ will require corresponding periods of quarantine or 'self-isolation'. The varied duration of 'mismatches'-e.g., due to incubation exceeding, or lasting longer than latency periods ${ }^{10}$ —imply that countries need to urgently acquire the ability to rapidly and reliably test as widely as necessary. As this has not been affordable for many, especially in poorer countries, the development of cheap, quick and reliable tests promises to be crucial. Once widely available and used, such improvements in the speed, reliability and affordability of testing will have significant consequences. ${ }^{11}$

No one can be exempted from preventive or containment measures until it is definitively medically confirmed that all those once infected can be neither infected or infectious again. For the time being, face masks and shields, physical distancing and hand hygiene remain vital to containment efforts. The long-term health and economic impacts of COVID-19 imply that public health and social protection systems should be well prepared to manage them.

Unfortunately, persuaded by the most influential, early western discourses, many politicians and others everywhere did not take the contagion threat seriously enough initially

\footnotetext{
9 The period between becoming infected with a pathogen and showing symptoms is called the 'incubation period'.

10 The 'latency period' is the time between becoming infected and being able to spread the disease to, i.e., infect others. There can be mismatches between the virus incubation period and the latency period. When the latency period is longer, an infected person may only display symptoms after they have actually become infectious, i.e., capable of infecting others. The SARS-CoV2 virus incubation period is generally longer than the latency period. Thus, an infected person can spread the virus before symptoms of having COVID-19 are visible.

11 A saliva-based laboratory diagnostic test developed by researchers at Yale to determine whether someone is infected with the novel SARS-CoV-2 virus was granted emergency use authorization by the US Food and Drug Administration (FDA) on 15 August 2020. With the technique made available on an open access basis, the cost and speed of testing can be radically reduced for all, with major implications for current precautionary and preventive practices and requirements. https://news.yale.edu/2020/08/15/yales-rapid-covid-19-saliv a-test-receives-fda-emergency-use-authorization. Accessed 21 August 2020. Since June, South Africa has been conducting trials for a 5-min COVID-19 breath test, while Israeli scientists claim to have developed a 30-s coronavirus breath test. https://www.the-scientist. com/news-opinion/in-south-africa-covid-19-breath-test-trial-set-forjune-67631; accessed 21 August 2020; https://medicalxpress.com/ news/2020-07-israeli-firm-second-coronavirus.html. Accessed 21 August 2020.
} 
for various reasons. These include not only cultural prejudice, but also misinformation and confidence in alternative approaches, such as 'herd immunity', ${ }^{12}$ all facilitated by the greater influence of social media.

If and when an effective vaccine becomes available, there is no guarantee that it will be affordable and available to all without a strong multilateral commitment to ensure that it quickly becomes universally accessible. Furthermore, there are likely to be significant populations who may refuse to be vaccinated en masse, e.g., where civil libertarian ideologies and mistrust of vaccines and authorities are pervasive. Without such a shared commitment to universal access, it may be impossible to completely eradicate the COVID-19 threat in the foreseeable future. ${ }^{13}$

Recent US actions have not been encouraging for a concerted global response to the pandemic. As the largest financial contributor, the US decision to formally withdraw from the WHO will certainly hamper its efforts, not only for dealing with the current pandemic, but also for preventing or preparing for the next viral epidemic (McKeever 2020). Earlier in April, President Trump, using a Korean War-era law, sought to redirect surgical masks manufactured by the US transnational firm $3 \mathrm{M}$ in other countries to the US, and to stop exporting masks manufactured by the company in the US (Swanson et al. 2020). ${ }^{14}$ The US confiscated 200,000 US-made face masks bound for Germany in Bangkok, and redirected them back to the US for use there, a move the German minister condemned as 'modern piracy'. ${ }^{15}$ US buyers also offered three times more to secure face masks from

\footnotetext{
12 https://theconversation.com/herd-immunity-wont-solve-our-covid -19-problem-139724. Accessed 22 August 2020.

13 More than 140 world leaders and experts signed an open letter before the World Health Assembly (WHA) began on 18 May, calling on governments to commit to a 'people's vaccine' against COVID19, also calling for all vaccines, treatments and tests to be patent-free, mass produced, fairly distributed and available to all, in every country, free of charge https://www.unaids.org/en/resources/presscentre/ pressreleaseandstatementarchive/2020/may/20200514_covid19-vacci ne. Accessed 21 August 2020. Although the leaders of China, Germany, France, Norway and Italy pledged at the WHA to make vaccines developed in their countries a global public good, the USA remains non-committal. The United Nations Secretary-General also emphasized that everybody must have access to the vaccine when available. The WHA unanimously acknowledged that vaccines, treatments and tests are global public goods, but was vague on the practical implications of the declaration. Since then, the US, the UK, Australia and other countries have signed up with the developers of 'candidate vaccines' to secure supplies for their own countries.

14 'Ceasing all export of respirators produced in the United States would likely cause other countries to retaliate and do the same, as some have already done', $3 \mathrm{M}$ said. 'If that were to occur, the net number of respirators being made available to the United States would actually decrease. That is the opposite of what we and the administration, on behalf of the American people, both seek' (Swanson et al. 2020).

15 https://www.bbc.com/news/world-52161995. Accessed 26 August 2020 .
}

China destined for France (Willsher et al. 2020). Meanwhile, 'Trump's trade policy is hampering the US fight against COVID-19, with Matt Rowan, president of the US Health Industry Distributors Association, warning 'against the impact that Trump's tariffs would have on the American health sector' (Bown 2020).

\section{COVID-19 Response Strategies}

\section{Early Action Crucial for Saving Lives and Livelihoods}

When the WHO declared COVID-19 a 'pandemic' on March 11 , more than $90 \%$ of cases were in four countries (China, Iran, Italy and South Korea), with new infections declining significantly in China and South Korea, 81 countries reporting no cases, and 57 reporting 10 cases or less (World Health Organization 2020a). Then, the WHO Director-General (DG) expressed the hope that countries could still check the pandemic by mobilizing resources to detect, test, isolate, trace and treat those infected, quarantining them while they remain infectious.

However, only a handful of East and Southeast Asian economies and Kerala state in southwest India acted early, urgently and adequately, thus avoiding highly disruptive total lockdowns and associated human and economic costs. They also secured greater community support for containment, while minimizing draconian enforcement measures. Had far more countries done so, while requiring safe physical distancing, mask wearing and other precautionary measures, the contagion could have been contained. And where communities or clusters had significant infection rates, urgent, targeted measures could have helped 'turn the tide' on COVID-19 with decisive early actions, as in China, Korea and Vietnam, without imposing nationwide 'stay in shelter' or 'shelter in place' lockdowns, ${ }^{16}$ or restrictions on movements of people within its borders.

Lulled into complacency, most others were slow to respond, with some hoping or expecting the virus would bypass them, or believing that 'herd immunity' would protect most exposed to the virus. A few headstrong, but very influential government leaders refused to acknowledge the severity of the COVID-19 threat, distracting many with conspiracy theories and 'blame games', instead of quickly learning from and correcting policy errors made as new knowledge became available.

In the UK, developing 'herd immunity' in the population, by allowing the epidemic to spread, prevailed as official policy until the first Imperial College of London (ICL) study was issued on 17 March. Much harm could have been avoided if early precautionary actions had been taken.

\footnotetext{
16 These terms are often used differently in various contexts, even changing over time.
} 
The WHO maintained that physical distancing, 'effective' hand washing and related sanitary practices were the most effective, practically 'do-able' and affordable, and apparently did not want to distract from such 'non-pharmaceutical interventions'. ${ }^{17}$ One problem has been that many people believe that wearing masks is sufficiently protective in lieu of physical distancing and hand washing.

But the use of protective face masks was actively discouraged by some national authorities, citing the very same WHO as the policy authority. ${ }^{18}$ The ostensible reason was to ensure adequate personal protective equipment (PPE) for 'frontline' workers, a view first associated with US presidential adviser, Anthony Fauci, as panic buying exhausted supplies and raised prices.

Thus, new infections and deaths quickly rose exponentially as the epidemic rapidly spread to other countries, especially to advanced countries in the West, better connected by passenger air travel. As developing countries struggle with inadequate vitally needed resources, many developed countries have acted in a jingoistic way by restricting exports of vital medical supplies, in contravention of the 2005 IHR and WHO recommendations.

\section{Flattening the Curve: Lockdowns Must not Deliver Economic Knockouts}

The principal strategy adopted by most governments is to 'flatten the curve', so that countries' health systems can cope with new infections by tracing, testing, isolating and treating those infected until an approved vaccine or 'cure' is available to all. But this is easier said than done.

If testing, contact tracing and other early containment measures had been adequately done in a timely manner to stem viral transmission, nationwide lockdowns would not have been necessary, and only limited areas would have had to be locked down for quarantine purposes. The effectiveness of containment measures, including lockdowns, are typically judged primarily by their ability to quickly reduce new infections, 'flatten the curve' and avoid subsequent waves of infections. However, lockdowns can have many effects, depending on context, and typically incur huge economic costs, unevenly

\footnotetext{
17 https://apps.who.int/iris/bitstream/handle/10665/330987/WHOnCov-IPC_Masks-2020.1-eng.pdf? sequence $=1 \&$ is Allowed=y. Accessed 21 August 2020.

18 Owing to the critical shortage of medical masks, the WHO's initial advice was to prioritize the use of face masks for people with COVID-19 symptoms, those looking after those infected and other 'frontline' personnel. The WHO revised its policy with new interim reccomendations on 5 June 2020, https://www.who.int/publications/i/ item/advice-on-the-use-of-masks-in-the-community-during-homecare-and-in-healthcare-settings-in-the-context-of-the-novel-coron avirus-(2019-ncov)-outbreak.
}

distributed in economies and societies. Most 'casual' labourers, petty businesses reliant on daily cash turnover, and others in the 'informal' economy typically find it especially difficult to survive extended lockdowns. Hence, success should not be measured by lockdown duration, enforcement stringency or even temporary declines in new cases.

Governments must be mindful of costs, including disruptions, and also of how policies affect various people differently. Lockdowns have undoubtedly set back economic and social progress and people's welfare, but public policy should be directed to make such setbacks reversible, and to ensure they do not deliver economic 'knockouts' to the vulnerable. Good planning, implementation and enforcement of movement restrictions, as well as adequate provisioning for those adversely affected, are crucial, not only for equity, efficacy and compliance, but also for transitions before, during, and after lockdowns.

Physical distancing, mask use and other precautionary measures, besides mass testing, tracing, isolation and treatment, have been able to check the contagion without resorting to draconian 'stay in shelter' lockdowns. Such measures have been quite successful so far in much of East Asia, Vietnam and Kerala. Precautionary measures must be appropriate and affordable. Those living in crammed conditions, e.g., urban slums, cannot realistically be expected to consistently practice safe distancing, but can nonetheless be enabled to sustainably take other precautionary measures within their modest means, e.g., by using washable masks or reusable shields in public areas. To minimize the risk of infection, authorities can encourage and enable, if not require, changes that demand 'physical distancing' in social interactions, including work and other public space arrangements, e.g., for offices, factories, shops, public transportation and classrooms.

\section{COVID-19 in Developing Countries}

\section{Developing Countries' Weak Health Systems}

Health systems in most developing countries are unevenly inadequate, even in normal times. Despite several pandemics in recent years, most countries have remained poorly prepared, even for the specific challenges posed by COVID-19. Even many health systems in Europe and North America have faced major shortages of doctors, respirators/ventilators, basic infection prevention (BIP) gear, PPE and testing kits. ${ }^{19}$

\footnotetext{
19 The WHO's shortened list includes: (a) guidelines for infection prevention; (b) pourable water and soap or hand disinfectant; (c) surface disinfectant; and (d) a waste bin. WHO guidance on PPE for those in direct contact with patients includes: (a) gloves; (b) face masks; (c) gowns or aprons; and (d) eye protection (WHO 2015, 2020b).
} 
A recent survey of the availability of four BIP and four PPE items in seven poor countries (Afghanistan, Bangladesh, Democratic Republic of Congo [DRC], Haiti, Nepal, Senegal and Tanzania) found less than a third of clinics and health centres in Bangladesh, the DRC, Nepal and Tanzania had any face masks (Gage and Bauhoff 2020). In all seven countries, clinics and health centres, often the first point of public contact with the health system, had, on average, just 2.3 (of four) BIP items and two (of four) PPE items. Most countries also scored poorly on health workers' preparedness with reference to the 2005 IHR to prevent disease spread.

While the US has about 33 intensive care unit (ICU) beds per 100,000 population, the ratio is around 2 per 100,000 in India, Pakistan and Bangladesh in South Asia. In sub-Saharan Africa, the situation is even more dire: Zambia has 0.6 ICU beds per 100,000, Gambia 0.4, and Uganda 0.1 (Malley and Malley 2020). In 43 of Africa's 55 countries, total ICU beds number less than 5000 , or about 5 beds per million, compared with about 4000 per million in Europe. There are also serious respirator shortages in Africa, with 41 African countries together having fewer than 2000 as of mid-April, and ten with none at all, while the US had 170,000 respirators in mid-March (Maclean and Marks 2020). The average low-income country has 0.2 physicians and 1.0 nurses per thousand people, compared to 3.0 and 8.8 respectively in high-income countries (Gage and Bauhoff 2020).

Global markets for crucial WHO designated COVID19 products are highly concentrated (Espitia et al. 2020). The EU, US, China, Japan and Korea-account for $80 \%$ of total imports. The import shares of products needed for case management and diagnostics are even higher, close to $90 \%$. Import shares for PPE and hygiene products are somewhat lower, around $50-60 \%$, requiring countries to compete on the basis of their respective means, regardless of need.

Developing countries are also extremely vulnerable to changes in exporter policies, such as export restrictions on COVID-19 tests, treatments and PPE. Besides affecting availability, export restrictions-supposedly due to domestic shortages-have pushed up world prices. Espitia et al. (2020) estimate that current export restrictions could initially increase prices of medical masks by $20.5 \%$, Venturi masks by $9.1 \%$, and protective equipment, such as aprons and gloves by $1 \%$ and $2 \%$ respectively. If exporting countries tighten export restrictions in response to domestic price rises, prices of such COVID-19 relevant goods could rise by $23 \%$ on average; most affected would be PPE, such as aprons (52\% increase) as well as goggles and masks (40\% increase) (Espitia et al. 2020).

Therefore, as high-income countries scramble to secure crucial supplies such as face masks, low-income countries face much tougher choices. Their budgets are far more limited, and they typically lack local producers for most PPE, relying on donors and multilateral organizations for procurement in the face of unreliable supply chains.

The COVID-19 threat to frontline health workers in lowincome countries has been largely ignored. Only a small fraction of needed PPE has gone to them. The WHO has dispatched 0.5 million PPE sets, while UNICEF has dispatched 100,000 N95 masks, 4.3 million gloves and other PPE. Billionaire philanthropist Jack Ma has donated 100,000 masks and 1000 protective suits each to every African country and 1.8 million masks to 10 Asian countries (Gage and Bauhoff 2020).

In recent decades, developed economies, through the IMF and World Bank, have used aid conditionalities to demand fiscal cuts and neoliberal health reforms, e.g., by imposing user fees in developing countries (Lister and Labonté 2009). Instead of improving efficiency, quality and coverage, these reforms have had deleterious implications for public health, besides exacerbating inequalities in access to health care (Stubbs and Kentikelenis 2017; Forstera et al. 2019; Sobhani 2019).Their structural adjustment programmes in developing countries, particularly in Africa, have resulted in underinvestment in health care systems, causing them to be poorly prepared to respond to the Ebola epidemic (Nkwanga 2015). Besides IMF and World Bank programmes, such underinvestment was also due to compromised fiscal capacities and regressive fiscal priorities (Sanders et al. 2015; Scott et al. 2016).

\section{Developing Country Responses}

With no known effective treatment for the infection, as the deadly nature of the virus became clear, many countries, even the world's most 'advanced' and richest, have adopted draconian measures, such as total or nationwide 'stay in shelter' lockdowns, often in panic and ignorant of other options. Accustomed to adopting supposed 'best practices' prescribed by the rich and powerful, all too many developing country governments are implementing such measures without sufficiently taking into account country-specific circumstances and other challenges. Besides the obvious differences between developed and developing countries, especially in terms of resources, demography, governance and other institutional capacities, there are significant differences among the developing countries themselves.

In most slums and villages, many people often live together in one or two rooms, sharing common facilities. Safe physical distancing is virtually impossible in such circumstances. Even basic hygiene and other prescribed sanitary measures are not easy when even clean running water is scarce. ${ }^{20}$

\footnotetext{
${ }^{20} \mathrm{Up}$ to $75 \%$ of people in the least developed countries lack access to soap and water. https://www.undp.org/content/undp/en/home/newscentre/news/2020/COVID19_Crisis_in_developing_countries_threa tens_devastate_economies.html, Accessed 27 July 2020.
} 
Most of the population in many developing countries is in the informal sector, earning meagre, typically daily incomes, and with paltry savings. All too many developing countries do not have enough fiscal space to provide sufficient relief for vulnerable populations and small businesses for very long. Hence, extending strict lockdown measures and causing an economy to be locked down for too long may erode public support, even if high at the outset. But as it is often too late to rely solely on early preventive and precautionary measures, authorities typically see no choice but to implement strict and effective contagion containment at the expense of disrupting livelihoods. This dilemma is often misrepresented as choosing between life and the economy.

Transmission patterns are determined by many factors, some social, local and intimate. International and even national public health decision makers are often oblivious to some such factors, which community members know all too well. Therefore, joint learning, involving both experts and affected communities, can be vital for effective responses.

\section{Selected Country Experiences}

Brazil and Peru are two of the worst hit countries in Latin America, but for different reasons. While the failure in Brazil has been due to complacency, denial and lack of national/ social solidarity, the Peruvian setback has been due to poor design of relief measures. Despite life-threatening risks, Brazil's President Bolsonaro chose to emulate US President Trump, infamously comparing the COVID-19 threat to a 'little flu' or 'cold', even dismissing it as a media-hyped 'fantasy (Borges 2020). He also dismissed preventive measures as 'hysterical' and repeatedly demanded that state governors withdraw their physical distancing and stay-in-shelter lockdown orders. Displeased by his public remarks on the need for lockdowns and physical distancing, Bolsonaro fired his health minister, causing outrage across Brazil. Lockeddown citizens of Brazil protested, even charging 'Bolsonaro Murder' (Quinn 2020). Instead of an 'all of government' approach, Bolsonaro also started disputes with Brazil's Congress and Supreme Court (Oliveira 2020; Santos 2020; BBC News 2020).

Peru, on the other hand, acted early and as decisively as Argentina, but met with different outcomes. Peru imposed lockdowns, closed schools and borders, cancelled international flights, and introduced relief measures. But its response was flawed as the government had not sufficiently considered the country's socio-economic conditions. For example, most poor Peruvians living in slums do not have bank accounts, and had to stand long hours queuing for cash relief grants. Ironically, this became a major cause of contagion (Ghitis 2020). The government's relief and preventive public health measures did not address the needs of the most vulnerable sectors of society, including the poor, self-employed, informally employed, Indigenous communities and indebted middle-income households. Rather, the government targeted its subsidies at large companies, who were presumed to be the major employers. Its safety-net programmes were based on census and municipality records, suffering serious data deficiencies. Hence, government measures barely reached those in greatest need (Martínez 2020). More than $21 \%$ of Peru's population live in extreme poverty, with around $70 \%$ in the informal sector depending on daily work for their livelihoods. While poor people, especially in cities, find it almost impossible to comply with lockdown restrictions as they struggled to survive, officials and much of the media portrayed them as 'irresponsible'. Trust and community support for government measures were undermined with the revelation of corruption scandals in the procurement of sanitary, protective, testing, medical and other supplies (Martínez 2020).

Other resource constrained developing countries, like Vietnam and Argentina, and India's Kerala state have tackled the pandemic far more effectively, at low cost and with impressive results. Some key features of their policy responses are highlighted below:

\section{Community Consultations}

The Kerala state government invited religious leaders, local bodies and civil society organisations (CSOs) to participate in policy design and implementation. It refused to use the term 'social distancing', which has caste and class connotations, and instead emphasized 'physical distancing' as part of a more socially inclusive approach to more people-centric development practices based on social solidarity. It carefully crafted political messages, such as 'Break the Chain', with larger political connotations, e.g., breaking the chains of oppression and popular emancipation.

\section{Social Mobilization and Solidarity}

Instead of using the pandemic for political advantage against Argentina's long history of fiercely divisive politics, President Alberto Fernandez invited and stood together with leaders from across the political spectrum when he announced lockdown measures on 19 March in a rare display of national political consensus (Gillespie and Do Rosario 2020). Social, religious and business groups partnered to deliver food cartons to more than two million people in Buenos Aires and the surrounding areas (Alcoba 2020). The Argentine national government has worked closely with opposition party state governors, as well as private and union-linked 
health providers to secure private cooperation without nationalization (WHO 2020c). Fernandez organized another display of national unity to announce that Argentina would not pay external creditors while dealing with the pandemic, demanding favourable debt-restructuring terms, a bold approach which appears to be working.

The Kerala state government mobilized more than 300,000 volunteers to help implement various infection control measures. It successfully mobilized CSOs to support its 'Break the Chain' awareness campaign, and got numerous micro-enterprises to produce hand sanitizers and face masks, while distributing interest-free loans worth 200 billion rupees to needy families (Krishna 2020). In Vietnam, citizens were encouraged-via social media, text messages and TV broadcasts- to donate to the campaign to buy medical and protective equipment for doctors, nurses, police and soldiers in close contact with patients, and for those quarantined. ${ }^{21}$

\section{Preventing Stigmatization}

Both the Kerala and Vietnam governments took measures to prevent stigmatization. The Kerala government organized hundreds of community kitchens with the help of CSOs and local-level leaders to discreetly deliver free meals to those infected with the virus, without publicly identifying them to avoid possible social stigmatization (Krishna 2020).

In Vietnam, the identities of those infected were protected by only referring to them by their case numbers. When local businesses were reportedly ostracizing foreigners, Vietnam's prime minister spoke out against such discrimination. ${ }^{22}$ Such measures encouraged people to be more open and cooperate fully in contact-tracing, testing and treatment.

\section{All of Government Approach}

Administrations that have successfully managed the pandemic have mobilized the all of government and demonstrated effective coordination among government departments and between their various layers. For example, the Kerala government set up 18 inter-departmental committees involving all branches of government, which meet daily to evaluate the situation. Vietnam's National Steering Committee for COVID-19 Prevention and Control was nicknamed the 'General Headquarters' - a reference to a

\footnotetext{
21 Viet Nam News 6 April, 2020. https://vietnamnews.vn/socie ty/674747/text-message-support-raises-54m-for-covid-19-prevention -control.html Accessed 3 June 2020.

22 VOA News. Vietnam orders national isolation after initial containment of coronavirus. VOA News. 31 March, 2020. https://www.voane ws.com/science-health/coronavirus-outbreak/vietnam-orders-natio nal-isolation-after-initial-containment, Accessed 3 June 2020.
}

military coordinating body in existence until the War ended in 1975. In Argentina, the Chief of the Cabinet of Ministers has responsibility for the "General Coordination Unit of the Comprehensive Plan for the Prevention of Public Health Events of International Importance'.

\section{Transparency and Communication}

The Kerala government organized daily press conferences, when the state Health Minister and Chief Minister calmly explained what was going on and what her department was doing. Communities were provided with essential epidemiological information to better understand the threat and related issues, to ensure compliance with prescribed precautionary measures and to avoid inadvertently causing panic.

Vietnam has not shied away from broadcasting the seriousness of the COVID-19 threat, with the Ministry of Health's online portal immediately publicizing each new case with details including location, mode of infection and action taken. Exceptionally, Vietnam's communist partyled government published the identity and itinerary of a prominent party figure who had tested positive (Vinh Le and Nguyen 2020). Instead of communicating in traditionally formal ways, the government has been creative, e.g., by teaming up with two famous pop singers to produce, promote and broadcast an effectively educational song about the threat. It has also commissioned artists to create posters, and mobilized influential youth figures to broadcast supportive messages to raise the morale of those quarantined and others as appropriate (Bui 2020).

\section{Lockdown with a Human Face}

Some governments and other authorities designed effective relief measures with consideration of challenges posed by specific conditions, including urban slum environments. For example, Argentina's President Alberto Fernández ensured that no essential services-electricity, gas, water, mobile services, fixed landlines, internet and cable television-were cut for retirees, social welfare recipients and low-income households on account of non-payment of bills (Sugarman 2020). Argentina's government has devoted over US $\$ 30$ million for food assistance alone. At national, provincial and municipal levels, the government has supported public kitchens, while the President has promised those in desperate circumstances the food and other resources needed to survive (Alcoba 2020).

In a similar vein, the Kerala state government has organized the physical delivery of food, medicine and other essentials as well as necessary services to those under lockdown (Krishna 2020). It took immediate actions to reduce the risk of hunger and starvation of the poorest segments of the 
population by organizing free rations for all for a month, distributing food kits, consisting of 17 items for every household, irrespective of income status (Pothan et al. 2020).

Kerala and Vietnam have been internationally acclaimed as role models, especially as they are both considered poor, and suffering resource constraints. By acting early, decisively and inclusively, Kerala and Vietnam successfully avoided highly disruptive total lockdowns as well as associated human and economic costs. They achieved a high level of buy-in and popular support for their governments' COVID-19 containment measures. As they achieved a high degree of voluntary compliance, draconian enforcement measures to 'flatten the curve' did not have to be imposed.

\section{Conclusion}

While COVID-19 crisis challenges are undoubtedly unique, they are not exceptional insofar as such challenges all have unique characteristics. Nevertheless, the challenges have probably been far greater than for other recent epidemics, raising questions about earlier tested modes of response.

Full social mobilization is undoubtedly needed, but such exceptional 'emergency' or even 'wartime-like' measures must not be abused, e.g., by the temptation to skew implementation for despotic, political or pecuniary advantage. Hence, success can be greatly enabled by legitimate, credible and exemplary leadership, government and otherwise.

Countries can have less disruptive and less costly, but yet very effective containment strategies, especially if they act early, quickly and adequately. The ability to trace and test as many suspected cases as possible, e.g., those who have recently come into close physical proximity with an infected person, is also crucial.

Effective containment depends heavily on voluntary compliance, and hence, community acceptance and trust, helped by transparency and shared understanding of what needs to be done. All these require state capabilities working together ('all of government') as well as credible and inclusive leadership to mobilize and co-ordinate the 'whole of society' for effective containment of contagion, as in the southwest Indian state of Kerala and Vietnam.

Acknowledgements The article is based on authors' opinion pieces in Inter Press Service (IPS) News Agency, which can be assessed at https://www.ipsnews.net/author/anis-chowdhury/; and https://www. ipsnews.net/author/jomo-kwame-sundaram/. The authors would like to thank Professor MJ Cardosa for her advice, comments and suggestions to improve the readability of the article, and Lim Siang Jin for his editorial advice, but implicate neither in the final version.

\section{References}

Alcoba, Natalie. 2020. Argentina's poorest barrios caught between coronavirus and hunger. Aljazeera. 14 April. https://www.aljaz eera.com/indepth/features/argentina-poorest-barrios-caught-coron avirus-hunger-200413115300648.html. Accessed 28 August 2020.

BBC News. 2020. Brazil. Federal court prohibits government from running campaign against social isolation. 28 March, https://www. bbc.com/portuguese/brasil-52077132. Accessed 18 October 2020.

Borges, Anelise. 2020. 'A little flu': Brazil's Bolsonaro playing down corona virus crisis. Euronews. 10 April, 2020. https://www.euron ews.com/2020/04/06/a-little-flu-brazil-s-bolsonaro-playing-downcoronavirus-crisis. Accessed 28 August 2020.

Bown, Chad. 2020. Trump's trade policy is hampering the US fight against COVID-19. Peterson Institute for International Economics, Washington, DC, 13 March. https://www.piie.com/blogs/ trade-and-investment-policy-watch/trumps-trade-policy-hampe ring-us-fight-against-covid-19. Accessed 26 August 2020.

Bui. Trang. 2020. Aggressive testing and pop songs: how Vietnam contained the coronavirus. The Guardian. 2 May. https://www. theguardian.com/commentisfree/2020/may/01/testing-vietnamcontained-coronavirus. Accessed 3 June 2020.

Christakis, Nicholas. 2020. Fighting covid-19 by truly understanding the virus. The Economist, 10 August. https://www.econo mist.com/by-invitation/2020/08/10/nicholas-christakis-on-fight ing-covid-19-by-truly-understanding-the-virus?fsrc=newsletter \&ut\%E2\%80\%A6. Accessed 20 August 2020.

Espitia, Alvaro, Nadia Rocha and Michele Ruta. 2020. Trade and the COVID-19 crisis in developing countries. 9 April. https:// voxeu.org/article/trade-and-covid-19-crisis-developing-count ries. Accessed 3 November 2020.

Faiola, Anthony, Sudarsan Raghavan, Max Bearak and Terrence McCoy. 2020. Public Health Experts: Coronavirus Could Overwhelm the Developing World. The Washington Post, 1 April. https://www.washingtonpost.com/world/the_americas/ coronavirus-developing-world-brazil-egypt-india-kenya-venez uela/2020/03/31/d52fe238-6d4f-11 ea-a156-0048b62cdb51_ story.html. Accessed 8 August 2020.

Forstera, Timon, Alexander Kentikelenis, Thomas Stubbs and Lawrence King. 2019. Globalization and Health Equity: The Impact of Structural Adjustment Programs on Developing Countries. Social Science \& Medicine. https://www.sciencedirect.com/science/artic le/pii/S0277953619304897. Accessed 4 August 2020.

Gage, Anna, and Sebastian Bauhoff. 2020. Health Systems in LowIncome Countries Will Struggle to Protect Health Workers from Covid-19. Center for Global Development, Washington, DC. https://www.cgdev.org/blog/health-systems-low-income-count ries-will-struggle-protect-health-workers-covid-19. Accessed 3 August 2020.

Ghitis, Frida. 2020. Why Even Peru's top-notch plans failed to stop the coronavirus pandemic. World Politics Review. 28 May, 2020. https://www.worldpoliticsreview.com/articles/28795/why-evenperu-s-top-notch-plans-failed-to-stop-the-coronavirus-pandemic. Accessed 28 August 2020.

Gillespie, Patrick, and Jorgelina Do Rosario. 2020. Argentina sacrifices economy to ward off virus, winning praise. Bloomberg. 28 March. https://www.bloomberg.com/news/articles/2020-03-27/argentinasacrifices-economy-to-ward-off-virus-winning-praise ${ }_{2}$ Accessed 28 August 2020.

Krishna, Yadul. 2020. India's Kerala is combating COVID-19 through participatory governance. The Bullet. 28 May, https://socialistp roject.ca/2020/05/india-kerala-combating-covid19-participatorygovernance/\#more. Accessed 1 June 2020.

Lister, John, and Ronald Labonté. 2009. Globalization and Health System Change. In Ronald Labonté, Ted Schrecker, Corinne Packer 
and Vivien Runnels (eds). Globalization and Health: Pathways, Evidence and Policy. Routledge, New York.

Maclean, Ruth, and Simon Marks. 2020. 10 African Countries Have No Ventilators. The New York Times, 20 April. https: //www. nytimes.com/2020/04/18/world/africa/africa-coronavirus-venti lators.html. Accessed 3 August 2020.

Malley, Robert, and Richard Malley. 2020. When the Pandemic Hits the Most Vulnerable: Developing Countries Are Hurtling Toward Coronavirus Catastrophe. Foreign Affairs, 31 March. https://www. foreignaffairs.com/articles/africa/2020-03-31/when-pandemichits-most-vulnerable. Accessed 3 August 2020.

Martínez, Alejandra Dinegro. 2020. Peru passes coronavirus risk to working class. Nacala. 19 May. https://nacla.org/ news/2020/05/19/peru-coronavirus-working-class. Accessed 28 August 2020

McKeever, Amy. 2020. Here's what we'll lose if the U.S. cuts ties with the WHO. National Geographic, 10 July. https://www.natio nalgeographic.com/science/2020/07/what-we-will-lose-if-unite d-states-cuts-ties-with-world-health-organization/. Accessed 26 August 2020.

Muggah, Robert, and Richard Florida. 2020. COVID-19 will hit the developing world's cities hardest. Here's why. World Economic Forum, 27 May. https://www.weforum.org/agenda/2020/05/covid -19-will-hit-the-developing-worlds-cities-hardest-heres-why/. Accessed 27 July 2020.

Nkwanga, Waiswa. 2015. The Ebola Crisis in West Africa and the Enduring Legacy of the Structural Adjustment Policies. https:// blogs.lse.ac.uk/africaatlse/2015/01/26/the-ebola-crisis-in-westafrica-and-the-enduring-legacy-of-the-structural-adjustment-polic ies/. Accessed 4 August 2020.

Oliveira, Mariana. 2020. Alexandre de Moraes suspends section of MP that changed rules of the Access to Information Law. Policy, 26 March. https://g1.globo.com/politica/noticia/2020/03/26/alexa ndre-de-moraes-suspende-mp-que-alterou-atendimento-a-lei-deacesso-a-informacao.ghtml. Accessed 18 October 2020.

Porras, Borja Santos. 2020. Controlling COVID-19 will carry devastating economic cost for developing countries. Conversation, 2 June. https://theconversation.com/controlling-covid-19-will-carry-devas tating-economic-cost-for-developing-countries-139492. Accessed 27 July 2020.

Pothan, Pramitha Elizabeth, Makiko Taguchi and Guido Santini. 2020. Local food systems and COVID-19; a glimpse on India's responses. FAO, 22 April. https://www.fao.org/in-action/foodfor-cities-programme/news/detail/en/c/1272232/. Accessed 28 August 2020.

Quinn, Colm. 2020. Bolsonaro fires Brazil's health minister as infections grow. Foreign Policy. 17 April, 2020. https://foreignpolicy. com/2020/04/17/jair-bolsonaro-brazil-fires-heath-minister-mande tta-coronavirus-inections-grow/. Accessed 28 August 2020.

Sanders, David, Amit Sengupta, and Vera Scott. 2015. Ebola Epidemic Exposes the Pathology of the Global Economic and Political System. International Journal of Health Services 45 (4): 643-656.

Santos. R. 2020. Judge suspends Bolsonaro decree that takes churches and lottery out of quarantine. Conjur newsletter. 29 March.

Scott, Vera, Sarah Crawford-Browne, and David Sanders. 2016. Critiquing the Response to the Ebola Epidemic Through a Primary Health Care Approach. BMC Public Health 16 (410): 1-9.

Sobhani, Saeed. 2019. From Privatization to Health System Strengthening: How Different International Monetary Fund (IMF) and
World Bank Policies Impact Health in Developing Countries. Journal of the Egyptian Public Health Association 94: 10. https ://jepha.springeropen.com/articles/10.1186/s42506-019-0013-x. Accessed 4 August 2020.

Stubbs, Thomas, and Alexander Kentikelenis. 2017. International Financial Institutions and Human Rights: Implications for Public Health. Public Health Review 38: 27. https://publichealthrev iews.biomedcentral.com/articles/10.1186/s40985-017-0074-3. Accessed 4 August 2020.

Sugarman, Jacob. 2020. Argentina Is Showing the World What a Humane Covid-19 Response Looks Like, The Nation. 16 April. https://www.thenation.com/article/politics/coronavirus-argentinahumane-response-to-covid-19-look-like/. Accessed 2 September 2020.

Swanson, Ana, Zolan Kanno-Youngs and Maggie Haberman. 2020. Trump Seeks to Block 3M Mask Exports and Grab Masks From Its Overseas Customers. The New York Times, 3 April. https:// www.nytimes.com/2020/04/03/us/politics/coronavirus-trump -3m-masks.html. Accessed 26 August 2020.

Vinh Le, Trien, and Huy Quynh Nguyen. 2020. How Vietnam Learned from China's coronavirus mistakes. The Diplomat. 17 March. https://thediplomat.com/2020/03/how-vietnam-learned-fromchinas-coronavirus-mistakes/1/. Accessed June 2020.

Willsher, Kim, Oliver Holmes, Bethan McKernan and Lorenzo Tondo. 2020. US hijacking mask shipments in rush for coronavirus protection. The Guardian, 3 April. https://www.theguardian.com/ world/2020/apr/02/global-battle-coronavirus-equipment-masks -tests. Accessed 26 August 2020.

Wolf, Martin. 2020. Covid-19 will hit developing countries hard. Financial Times, 10 June. https://www.ft.com/content/31eb2 686-a982-11ea-a766-7c300513fe47. Accessed 27 July 2020.

Woodley, Matt. 2020. How Does Coronavirus Compare with Previous Global Outbreaks? The Royal Australian College of General Practitioners, 19 February. https://www1.racgp.org.au/newsgp/ clinical/how-does-coronavirus-compare-with-previous-global. Accessed 3 August 2020.

World Health Organization (WHO). 2015. Service Availability and Readiness Assessment (SARA). https://www.who.int/healt hinfo/systems/SARA_Reference_Manual_Chapter3.pdf?ua=1. Accessed 3 August 2020.

World Health Organization (WHO). 2020a. WHO Director-General's Opening Remarks at the Media Briefing on COVID-19, 11 March. https://www.who.int/dg/speeches/detail/who-director-general-sopening-remarks-at-the-media-briefing-on-covid-19---11-march -2020. Accessed 3 August 2020.

World Health Organization (WHO). 2020b. Rational Use of Personal Protective Equipment (PPE) for Coronavirus Disease (COVID19), 19 March. https://apps.who.int/iris/bitstream/handle/10665 1331498/WHO-2019-nCoV-IPCPPE_use-2020.2-eng.pdf. Accessed 3 August 2020.

World Health Organization (WHO). 2020c. Argentina: there is no economy without health. WHO. 29 July. https://www.who.int/newsroom/feature-stories/detail/argentina-there-is-no-economy-witho ut-health. Accessed 28 August 2020.

Publisher's Note Springer Nature remains neutral with regard to jurisdictional claims in published maps and institutional affiliations. 